\section{UAB}

Universitat Autònoma de Barcelona

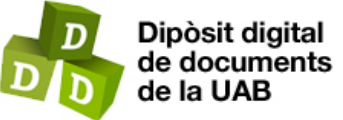

de la UAB

This is the accepted version of the article:

Piaggio, Matías; Alcántara, Vicent; Padilla, Emilio. «GREENHOUSE

GAS EMISSIONS AND ECONOMIC STRUCTURE IN URUGUAY».

Economic Systems Research, Vol. 26 Núm. 2 (2014), p. 155-176. DOI $10.1080 / 09535314.2013 .869559$

This version is available at https://ddd.uab.cat/record/247660

under the terms of the (c) BY-NC-ND license 
This is the postprint version of the article:

Piaggio, M., Alcántara, V., Padilla, E. (2014) "Greenhouse gas emissions and economic structure in Uruguay", Economic Systems Research, Vol. 26 (2), pp. 155176.

https://doi.org/10.1080/09535314.2013.869559

\title{
Greenhouse gas emissions and economic structure in Uruguay
}

\begin{abstract}
Using input-output analysis, we identify the key sectors in greenhouse gas emissions of the Uruguayan economy. The responsibilities of each sector in terms of its emissions are decomposed into an own component, generated during the activities of the sector, and an indirect component, generated by the induced activities in other sectors. This has important implications for the design of mitigation polices, as the appropriate policy measures are contingent on the nature of the pollution. Technical improvements and best practices are effective only when applied to directly polluting sectors, while demand policies may be more appropriate for indirectly polluting sectors. In addition, we analyze pollution generated during the production of exports.
\end{abstract}

The results show that demand policies are going to be effective in the Building, the Hotel and restaurants, and the Wholesale and retail trade; repair of motor vehicles and motorcycles sectors. These policies complement greenhouse gas emissions mitigation policies in directly polluting sectors (mainly the Cattle farming and the transport related sectors). Finally, methane and nitrous oxide emissions are mainly the consequence of production for exports, while carbon dioxide emissions are mainly driven by production for domestic consumption.

Keywords: Greenhouse gas emissions, input-output, key sectors, Uruguay.

JEL classification: C67, Q40, Q43, Q56 


\section{Introduction}

During the 1992 Rio Summit, the attending countries drew up the United Nations Framework Convention on Climate Change to cooperatively limit average global temperature increases and the resulting impacts of climate change. Five years later the Kyoto Protocol was adopted, legally binding developed countries (Annex B) to emission control targets. In 2007, the Bali Action Plan called for developing countries to implement nationally appropriate mitigation actions (NAMAs) in a measurable, reportable, and verifiable manner.

The production structure plays a salient role in the relationship between the economy and the environment. Environmentally-extended input-output (IO) analysis allows for a more complete understanding of the relationship between the economy and material flows, which is essential for better understanding environmental problems and designing policies to solve them (Hoekstra, 2005).

Methane and nitrous oxide emissions, mainly produced by the Cattle farming sector, represent $83 \%$ of total Uruguayan greenhouse gases (GHG). The remaining $16.6 \%$ are carbon dioxide emissions, and the main direct polluters are the transport-related sectors (43.2\%). In this context, and for mitigation policy design, it is relevant to know whether the polluting sectors are producing output for final demand or as inputs for other sectors.

The general objective of this paper is to identify key polluting sectors of the Uruguayan economy in order to orientate the design of mitigation policy. To this end, three specific objectives are defined: i) organizing detailed data for carbon dioxide $\left(\mathrm{CO}_{2}\right)$, methane $\left(\mathrm{CH}_{4}\right)$ and nitrous oxide $\left(\mathrm{N}_{2} \mathrm{O}\right)$ emissions from productive activities and relating these to the national accounts structure, in order to come up with a tentative proposal for environmental accounts for Uruguay; ii) identifying the most significant polluting sectors in terms of their GHG emissions in Uruguay, and iii) determining if these sectors are important because they pollute themselves or induce other sectors to pollute.

Rasmussen (1952) proposed IO analysis to measure structural interdependence through backward and forward inter-industry multipliers. Hirschman (1958) suggested to use this concept to identify key sectors in the economy, arguing that economic development 
and structural change are driven by sectors with above-average multipliers. Sectors with greater linkages generate greater externalities, meriting government intervention (Jones, 1976). Thus, environmentally-extended key sector analysis is useful for mitigation policy design, as it allows for the identification of sectors in which mitigation policies are likely to be most effective.

The early approaches in key sector analysis consider inter-industry linkages through Leontief demand-pull multipliers. However, this approach does not consider the weights of the different sectors in the economy, a refinement which emerged in linkages literature after the approach advanced by Rasmussen/Hirschman. This concept is almost fully coincident with the simple Leontief demand-pull multipliers. Linkage analysis has been traditionally employed to identify clusters of sectors that are significant for economic development (in our case, in reference to pollution). Without weighting multipliers, the relative importance of the sectors is ignored. Because of its simplicity and its capacity to shed light on our research questions, the key sector analysis is conducted here employing weighted Rasmussen/Hirschman multipliers.

It is important to distinguish if a sector pollutes through its own production process (directly and indirectly) or if it is responsible for the pollution that other sectors generate when demanding inputs to them. To this end, key sector analysis is combined with multipliers decomposition analysis. Simple Leontief demand-pull multipliers cannot indicate whether a sector is polluting by itself or whether it is making other sectors to pollute. Hence, this step is essential to inform mitigation policy design, as different natures of the polluting components should be addressed with different policy measures. Technical improvements and better practices are effective mitigation policies in sectors with a high own backward component. Targeting these reduces pollution either from the sectors themselves or from other sectors. Sectoral measures to reduce emissions are not effective in sectors with a high pure indirect backward component because these sectors are not directly responsible for GHG emissions. In this case, technological or better practice measures are effective if they reduce intermediate demand to directly polluting sectors. Final demand measures can also be adopted, although this may not be attractive for policymakers, as it means reducing final demand for several sectors. 
In this paper we employ a production-based approach (domestic production including exports) based on the Intergovernmental Panel on Climate Change (IPCC) methodology for computing GHG emission inventories. However, it is also important to analyze the emissions embodied in the Uruguayan international trade. The production-based approach is defined from a territorial perspective that allows to develop domestic mitigation analysis and national policy design. Many critiques suggest including imports and leaving out exports-related emissions (consumption-based approach). This helps to determine the country's consumer responsibility, and is useful, for example, for correctly allocating tradable permits to stabilize GHG on a global scale (Kondo et al., 1998; Munksgraad and Pedersen, 2001; Lenzen et al., 2004; and Peters, 2008). Lenzen et al. (2007) proposed a shared responsibility approach balancing both extreme points of view. A consumption-based approach requires complex information that is not available for Uruguay for recent years. To alleviate this requirement, the domestic technology structure assumption for computing factors embodied in imported commodities has been widely employed in the literature. However, this has been demonstrated to be an implausible assumption for determining the emissions balance (Lenzen et al., 2004). Uruguay is a small economy based on agro-industrial exports. This makes the domestic technology structure assumption to be implausible in this case, because it is not possible to produce its imports domestically. Andrew et al. (2009), using data for 2001 based on an IO matrix for 1997, show that Uruguay is one of the countries for which the domestic technology structure assumption gives the most biased results for carbon dioxide multipliers. This is a consequence of the high weight of clean energy sources in its energy matrix, which differs from the technology generally employed to produce its imports. Because of this, a consumption-based approach under the domestic technology structure assumption is neither realistic nor useful for this case study. However, total national emissions from a production-based approach can be decomposed into those generated when producing exports and those embodied in goods and services for domestic consumption. This allows the benchmarking of the role of exports on national emissions.

The next section provides the details of the methodology and data employed. Section 3 shows and discusses the empirical results. Section 4 discusses policy implications and concludes. 


\section{Methodology}

There has been a long debate around the key sectors' concept since Rasmussen/Hirschman's traditional approach. ${ }^{1}$ Alternative perspectives on economic interdependence should not be regarded as exclusive, but as complementing each other (Sonis et al., 2000). Environmental extensions have been widely applied in the literature (Hoekstra, 2010). As regards GHG, key sectors applications have been developed for $\mathrm{CO}_{2}$ emissions in Spain (Alcántara and Padilla, 2006), and Brazil (Imori and Guilhoto, 2010). We employ the traditional Rasmussen/Hirschman approach extended to GHG emissions, because of its simplicity and capacity to answer our research questions. The analysis is developed both for unweighted and weighted multipliers. This allows to distinguish those sectors that pollute just because of their technology from those that are also important because of their weight in the economy.

In addition to key sector analysis, it is important to decompose multipliers to distinguish a sector's own emissions from those that are purely indirect. It is not only important to see if a sector is significant, but also if it is important because it involves many other sectors, or because it draws heavily on itself or a few other sectors. Relevant policies will vary depending on the nature of sector linkages (Alcántara et al., 2010). The next two subsections describe the methodology employed in the empirical analysis.

\subsection{Key sector analysis}

Leontief (1936) model defines matrix $\mathbf{L}=(\mathbf{I}-\mathbf{A})^{-\mathbf{1}}$ where $\mathbf{A}$ is a domestic inputs coefficient matrix, and its elements $a_{i j}$ denote the inter-industry flows from sector $i$ to sector $j$. The increase in the level of gross output required to hold a unit increase in final demand of a sector is defined by the sum of the columns of matrix $\mathbf{L}$. This analysis can be generalized to any relevant dimension. We define vector $\mathbf{c}_{1 \mathrm{xn}}$ as a row vector of coefficients that relates every sector to a specific pollutant. Hence, $\mathbf{c x}^{\prime}=e$ where $\mathbf{x}$ is the sector output vector and $e$ is a scalar that denotes total emissions. In this way $\mathbf{e}^{\prime}{ }_{\mathrm{n} \times 1}=\hat{\mathbf{c}}(\mathbf{I}-\mathbf{A})^{-\mathbf{1}} \mathbf{y}^{\prime}$ is defined, where $\mathbf{e}$ is a vector representing the direct sector emissions, $\mathbf{y}$ is the row vector of final demand, and matrix $\mathbf{F}_{\mathbf{y}}=\hat{\mathbf{c}}(\mathbf{I}-\mathbf{A})^{\mathbf{- 1}}$ is a linear

\footnotetext{
${ }^{1}$ Hewings (1982), Lenzen (2003) and Miller and Blair (2009) present comprehensive surveys on key sector analysis evolution. Sánchez-Chóliz and Duarte (2003) provide a general definition covering almost all definitions of linkage indicators.
} 
operator that converts final demand variations into variations in the emission vector. In this way demand-driven unweighted multipliers (backward linkages) extended to GHG emissions are defined as:

$$
\boldsymbol{\mu}_{\mathbf{y}_{1 \times n}}^{\mathrm{uw}}=\mathbf{u} \hat{\mathbf{c}}(\mathbf{I}-\mathbf{A})^{-1}
$$

Where $\mathbf{u}$ is a row summation vector. ${ }^{2}$ In order to avoid biased conclusions, multipliers can be weighted by final demand. This avoids giving much importance to small sectors that take an important part of their input from other sectors, while their weight in total output is not significant. In the case of emissions analysis, even though the variations in those sectors final demand have greater impact in pollution terms, their contribution to total emissions is less significant. Taken together, both perspectives are useful to distinguish those sectors that are important because of their technology from those where mitigation policies are more effective. So, if $\tilde{y}_{i}=\frac{y_{i}}{\sum_{i} y_{i}}$ and $\sum_{i} \tilde{y}_{i}=1$. Then equation (2) is obtained:

$$
\boldsymbol{\mu}_{\mathbf{y}_{1 \times \mathrm{n}}}^{\mathrm{w}}=\mathbf{u} \hat{\mathbf{c}}(\mathbf{I}-\mathbf{A})^{-1} \hat{\hat{\mathbf{y}}}
$$

Total sectoral embodied emissions (direct plus indirect) can be computed as $\mathbf{e}_{\mathrm{n} \times 1}^{\text {total'}}=$

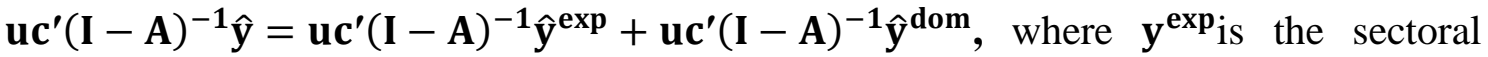
exports vector, while $\mathbf{y}^{\mathbf{d o m}}$ is a vector of final domestic demand. This allows total sectoral embodied emissions for satisfying exports and domestic demand to be computed.

The demand-driven model allows to identify the vector of total emissions generated per unit of final demand. Unweighted and weighted multipliers are classified in relation to their average multiplier, $\mu^{u w}=\frac{\boldsymbol{\mu}_{y}^{u w} \boldsymbol{u}^{\prime}}{n}$ and $\mu^{w}=\frac{\boldsymbol{\mu}_{y}^{w} \boldsymbol{u}^{\prime}}{n}$. Key sectors are defined as those with backward linkages above the average multiplier. Alternatively, in order to avoid

\footnotetext{
${ }^{2}$ The demand driven multiplier of sector $i$ in traditional IO analysis depicts the total output required per unit worth increase of its final demand. Different than this, in an IO model extended to GHG emissions, the demand driven multiplier of sector $i$ represents the total pollution impact when its final demand increases by one unit worth.
} 
classification biases because of outliers, the threshold could be defined by reference to the median multiplier.

Although multipliers are weighted to avoid biased results, it may be the case that an increase in the final demand for the product of a particular sector with high multipliers does not affect many other sectors. This happens in sectors that draw heavily on only one or a few sectors. Rasmussen (1952) proposes measuring multiplier variability by the coefficient of variation $(C V)$ indices as a complementary approach to control for sensitivity to extreme values. From a demand perspective, the $C V$ of sector $j$ is defined $\operatorname{as} C V_{j}^{y}=\frac{\sqrt{\frac{1}{n-1} \sum_{i=1}^{n}\left(l_{i j}-\frac{1}{n} \sum_{i=1}^{n} l_{i j}\right)^{2}}}{\frac{1}{n} \sum_{i=1}^{n} l_{i j}}$. A sector that shows a high value of the $C V$ from a demand perspective can be interpreted as a sector that draws heavily on only one or a few sectors, while if its value is low, it depicts a sector that purchases inputs evenly from other sectors.

\subsection{Own and pure indirect components decomposition}

Following Alcántara et al. (2010), the decomposition of an own and a pure indirect components can be made by subtracting matrix $\mathbf{F}_{\mathbf{y}}$ diagonal elements. Departing from (2), total GHG emissions from any sector per unit of total demand of sector $j$ can be defined as $\mu_{y_{j}}=\sum_{i} f_{\boldsymbol{y}_{i j}} \tilde{y}_{j}=f_{\boldsymbol{y}_{j j}} \tilde{y}_{j}+\sum_{i \neq j} f_{\boldsymbol{y}_{i j}} \tilde{y}_{j}$, where $f_{\boldsymbol{y}_{i j}}$ is the characteristic element of matrix $\mathbf{F}_{\mathbf{y}}$. Thus, the "own weighted backward component" can be written as:

$$
\mu_{y_{j}}^{w-o w n}=f_{y_{j j}} \tilde{y}_{j}
$$

and the "pure indirect weighted backward component" as:

$$
\mu_{\boldsymbol{y}_{j}}^{w-\text { pure }}=\sum_{i \neq j} f_{\boldsymbol{y}_{i j}} \tilde{y}_{j}
$$

The own weighted backward component indicates how variations in the final demand of a sector affect GHG emissions from the sector itself. The pure indirect weighted backward component denotes how variations in the final demand of a sector affect GHG emissions from other sectors. 
Own and pure indirect components decomposition is complementary to the $C V$. Sectors that show high own components are also expected to show a high $C V$. Moreover, a high pure indirect component depicts the importance of a sector because it makes others pollute. Along with the $C V$, this is useful to show whether it makes only one or a few sectors pollute, or whether it makes many of them pollute. It is relevant to note whether the production of a sector showing a significant pure indirect component is spread among many sectors, or is concentrated only in one or a few. If a sector shows both own and pure indirect significant components, the $C V$ omitting the main diagonal elements must be computed to avoid biases caused by the own component.

\subsection{Data}

There is no official IO matrix for Uruguay. However, in the benchmark of a Red Mercosur - Food and Agricultural Organization (FAO) agreement for technical assistance to the Agriculture, Livestock and Fishing Ministry, an IO table for the year 2005 was constructed under direct supervision of the Central Bank of Uruguay (BCU), the institution that publishes the national accounts information (Terra et al., 2009). There is a consensus on its validity, and it is the main reference for both public and private analysis. It is split into 56 activities at basic prices. 
Table 1: Productive sectors, output and GHG emissions

\begin{tabular}{|c|c|c|c|c|c|c|c|c|c|c|c|}
\hline Sector & Name & $\begin{array}{c}\text { Output } \\
\text { US\$ : }\end{array}$ & $\begin{array}{c}\% \\
\text { Output }\end{array}$ & $\begin{array}{c}\mathrm{CO}_{2} \\
\text { Ktons }\end{array}$ & $\% \mathrm{CO}_{2}$ & $\begin{array}{c}\mathrm{CH}_{4} \\
\text { Ktons }\end{array}$ & $\% \mathrm{CH}_{4}$ & \begin{tabular}{|c|}
$\mathrm{N}_{2} \mathrm{O}$ \\
Ktons
\end{tabular} & $\% \mathrm{~N}_{2} \mathrm{O}$ & $\begin{array}{l}\mathrm{CO}_{2} \mathrm{e} \\
\text { Ktons }\end{array}$ & $\% \mathrm{CO}_{2} \mathrm{e}$ \\
\hline 1 & Rice grow ing & 176.62 & $0.6 \%$ & 91.0 & $1.5 \%$ & 743.7 & $4.0 \%$ & 0.9 & $0.0 \%$ & 835.6 & $2.3 \%$ \\
\hline 2 & Other cereals and crops & 47.55 & $1.5 \%$ & 112.9 & $1.9 \%$ & 1.3 & $0.0 \%$ & 1.6 & $0.0 \%$ & 115.9 & $0.3 \%$ \\
\hline 3 & Vegetables and horticultural grow ing & 108.68 & $0.4 \%$ & 12.2 & $0.2 \%$ & 0.0 & $0.0 \%$ & 0.1 & $0.0 \%$ & 12.3 & $0.0 \%$ \\
\hline 4 & Fruits grow ing & 146.38 & $0.5 \%$ & 19.3 & $0.3 \%$ & 0.1 & $0.0 \%$ & 0.2 & $0.0 \%$ & 19.5 & $0.1 \%$ \\
\hline 5 & Raw milk and milk products prepared in & 235.49 & $0.8 \%$ & 65.4 & $1.1 \%$ & 1328.3 & $7.1 \%$ & 0.6 & $0.0 \%$ & 1394.3 & $3.8 \%$ \\
\hline 6 & Cattle farming & 987.90 & $3.4 \%$ & 63.1 & $1.0 \%$ & 15161.7 & $81.5 \%$ & 12039 & $99.8 \%$ & 27264.3 & $74.1 \%$ \\
\hline 7 & Other animal farming & 112.72 & $0.4 \%$ & 6.4 & $0.1 \%$ & 18.3 & $0.1 \%$ & 0.1 & $0.0 \%$ & 24.8 & $0.1 \%$ \\
\hline 8 & Forestry and logging & 138.67 & $0.5 \%$ & 5.3 & $0.1 \%$ & 0.0 & $0.0 \%$ & 0.0 & $0.0 \%$ & 5.4 & $0.0 \%$ \\
\hline 9 & Fishing & 65.67 & $0.2 \%$ & 169.3 & $2.8 \%$ & 0.2 & $0.0 \%$ & 1.1 & $0.0 \%$ & 170.6 & $0.5 \%$ \\
\hline 10 & Mining and quarrying & 64.39 & $0.2 \%$ & 11.4 & $0.2 \%$ & 0.0 & $0.0 \%$ & 0.0 & $0.0 \%$ & 11.5 & $0.0 \%$ \\
\hline 11 & Meat production & $1,426.40$ & $4.9 \%$ & 114.4 & $1.9 \%$ & 108.8 & $0.6 \%$ & 0.0 & $0.0 \%$ & 223.2 & $0.6 \%$ \\
\hline 12 & Fish processing and fish products & 172.15 & $0.6 \%$ & 0.0 & $0.0 \%$ & 0.7 & $0.0 \%$ & 0.0 & $0.0 \%$ & 0.7 & $0.0 \%$ \\
\hline 13 & $\begin{array}{l}\text { Fruit and vegetables processing and } \\
\text { preserving }\end{array}$ & 32.41 & $0.1 \%$ & 0.0 & $0.0 \%$ & 22.3 & $0.1 \%$ & 0.0 & $0.0 \%$ & 22.3 & $0.1 \%$ \\
\hline 14 & $\begin{array}{l}\text { Manufacture of vegetable and animal oils } \\
\text { and fats }\end{array}$ & 29.45 & $0.1 \%$ & 0.0 & $0.0 \%$ & 0.0 & $0.0 \%$ & 0.0 & $0.0 \%$ & 0.0 & $0.0 \%$ \\
\hline 15 & Dairy $p$ & 479.76 & $1.6 \%$ & 134.8 & $2.2 \%$ & 29.4 & $0.2 \%$ & 0.0 & $0.0 \%$ & 164.1 & $0.4 \%$ \\
\hline 16 & Rice mill products & 227.34 & $0.8 \%$ & 56.7 & $0.9 \%$ & 0.0 & $0.0 \%$ & 0.0 & $0.0 \%$ & 56.7 & $0.2 \%$ \\
\hline 17 & other grain mill & 74.37 & $0.3 \%$ & 0.8 & $0.0 \%$ & 0.0 & $0.0 \%$ & 0.0 & $0.0 \%$ & 0.8 & $0.0 \%$ \\
\hline 18 & himal feeds & 64.96 & $0.2 \%$ & 48.0 & $0.8 \%$ & 0.0 & $0.0 \%$ & 0.0 & $0.0 \%$ & 48.0 & $0.1 \%$ \\
\hline 19 & Bakery and similar farinaceous $p$ & 276.49 & $0.9 \%$ & 66.3 & $1.1 \%$ & 0.1 & $0.0 \%$ & 0.0 & $0.0 \%$ & 66.4 & $0.2 \%$ \\
\hline 20 & other food products & 336.91 & $1.2 \%$ & 41.4 & $0.7 \%$ & 0.0 & $0.0 \%$ & 0.0 & $0.0 \%$ & 11.5 & $0.1 \%$ \\
\hline 21 & Wines & 63.56 & $0.2 \%$ & 35.2 & $0.6 \%$ & 0.1 & $0.0 \%$ & 0.0 & $0.0 \%$ & 35.3 & $0.1 \%$ \\
\hline 22 & Manufacture of malt liquors and malt & 97.75 & $0.3 \%$ & 3.8 & $0.1 \%$ & 0.1 & $0.0 \%$ & 0.0 & $0.0 \%$ & 3.9 & $0.0 \%$ \\
\hline 23 & Distilling, rectifying and blending of spirits; & 151.05 & $0.5 \%$ & 32.7 & $0.5 \%$ & 0.2 & $0.0 \%$ & 0.0 & $0.0 \%$ & 32.9 & $0.1 \%$ \\
\hline 24 & Tobacco & 61.54 & $0.2 \%$ & 0.8 & $0.0 \%$ & 0.0 & $0.0 \%$ & 0.0 & $0.0 \%$ & 0.8 & $0.0 \%$ \\
\hline 25 & Spinning, w eaving and finishing of textiles & 252.86 & $0.9 \%$ & 69.9 & $1.1 \%$ & 38.1 & $0.2 \%$ & 0.0 & $0.0 \%$ & 108.0 & $0.3 \%$ \\
\hline 26 & Knitted and crocheted fabrics and articles & 59.01 & $0.2 \%$ & 12.5 & $0.2 \%$ & 0.0 & $0.0 \%$ & 0.0 & $0.0 \%$ & 12.5 & $0.0 \%$ \\
\hline 27 & $\begin{array}{l}\text { Dressing and dyeing of fur; manufacture of } \\
\text { articles of fur }\end{array}$ & 274.03 & $0.9 \%$ & 12.6 & $0.2 \%$ & 0.0 & $0.0 \%$ & 0.0 & $0.0 \%$ & 12.6 & $0.0 \%$ \\
\hline 28 & $\begin{array}{l}\text { Tanning and dressing and manufacture of } \\
\text { leather }\end{array}$ & 282.97 & $1.0 \%$ & 23.0 & $0.4 \%$ & 2.0 & $0.0 \%$ & 0.0 & $0.0 \%$ & 24.9 & $0.1 \%$ \\
\hline 29 & Footh & 37.89 & $0.1 \%$ & 2.6 & $0.0 \%$ & 0.0 & $0.0 \%$ & 0.0 & $0.0 \%$ & 2.6 & $0.0 \%$ \\
\hline 30 & Wood & 178.22 & $0.6 \%$ & 74.9 & $1.2 \%$ & 0.0 & $0.0 \%$ & 0.0 & $0.0 \%$ & 75.0 & $0.2 \%$ \\
\hline 31 & Paper and paper products & 149.15 & $0.5 \%$ & 162.4 & $2.7 \%$ & 0.1 & $0.0 \%$ & 0.0 & $0.0 \%$ & 162.5 & $0.4 \%$ \\
\hline 32 & $\begin{array}{l}\text { Publishing, printing and reproduction of } \\
\text { recorded media }\end{array}$ & 186.69 & $0.6 \%$ & 16.9 & $0.3 \%$ & 0.0 & $0.0 \%$ & 0.0 & $0.0 \%$ & 17.0 & $0.0 \%$ \\
\hline 33 & Refined petroleum & $1,026.82$ & $3.5 \%$ & 416.2 & $6.8 \%$ & 3.9 & $0.0 \%$ & 0.5 & $0.0 \%$ & 420.6 & $1.1 \%$ \\
\hline 34 & $\begin{array}{l}\text { Pesticides and other agro-chemical } \\
\text { products }\end{array}$ & 117.51 & $0.4 \%$ & 0.5 & $0.0 \%$ & 0.0 & $0.0 \%$ & 0.0 & $0.0 \%$ & 0.5 & $0.0 \%$ \\
\hline 35 & Pharm & 180.87 & $0.6 \%$ & 5.3 & $0.1 \%$ & 0.0 & $0.0 \%$ & 0.0 & $0.0 \%$ & 5.3 & $0.0 \%$ \\
\hline 36 & Basic & 363.65 & $1.2 \%$ & 21.1 & $0.3 \%$ & 0.1 & $0.0 \%$ & 0.0 & $0.0 \%$ & 21.2 & $0.1 \%$ \\
\hline 37 & plastics products & 305.95 & $1.0 \%$ & 1.5 & $0.0 \%$ & 0.0 & $0.0 \%$ & 0.0 & $0.0 \%$ & 1.5 & $0.0 \%$ \\
\hline 38 & allic mineral products & 206.59 & $0.7 \%$ & 475.2 & $7.8 \%$ & 0.3 & $0.0 \%$ & 0.0 & $0.0 \%$ & 475.6 & $1.3 \%$ \\
\hline 39 & Basic & 620.06 & $2.1 \%$ & 24.3 & $0.4 \%$ & 0.1 & $0.0 \%$ & 0.0 & $0.0 \%$ & 24.3 & $0.1 \%$ \\
\hline 40 & Motor & 171.69 & $0.6 \%$ & 0.2 & $0.0 \%$ & 0.0 & $0.0 \%$ & 0.0 & $0.0 \%$ & 0.2 & $0.0 \%$ \\
\hline 41 & Furniture & 189.84 & $0.6 \%$ & 0.0 & $0.0 \%$ & 0.0 & $0.0 \%$ & 0.0 & $0.0 \%$ & 0.0 & $0.0 \%$ \\
\hline 42 & Electricity, & 837.07 & $2.9 \%$ & 895.8 & $14.7 \%$ & 16.2 & $0.1 \%$ & 1.2 & $0.0 \%$ & 913.2 & $2.5 \%$ \\
\hline 43 & Building & $2,473.46$ & $8.5 \%$ & 7.1 & $0.1 \%$ & 0.0 & $0.0 \%$ & 0.0 & $0.0 \%$ & 7.1 & $0.0 \%$ \\
\hline 44 & $\begin{array}{l}\text { tail trade; repair of motor } \\
\text { cycles sectors }\end{array}$ & $3,096.67$ & $10.6 \%$ & 14.8 & $0.2 \%$ & 0.0 & $0.0 \%$ & 0.0 & $0.0 \%$ & 14.9 & $0.0 \%$ \\
\hline 45 & Hotels and restaurants & 867.28 & $3.0 \%$ & 26.3 & $0.4 \%$ & 0.0 & $0.0 \%$ & 0.1 & $0.0 \%$ & 26.4 & $0.1 \%$ \\
\hline 46 & Land transport; transport via pipeline & 957.48 & $3.3 \%$ & 1261.2 & $20.7 \%$ & 2.4 & $0.0 \%$ & 17.5 & $0.1 \%$ & 1281.1 & $3.5 \%$ \\
\hline 47 & Water & 875.27 & $3.0 \%$ & 1371.5 & $22.5 \%$ & 0.4 & $0.0 \%$ & 1.4 & $0.0 \%$ & 1373.3 & $3.7 \%$ \\
\hline 48 & ecommunications & 777.83 & $2.7 \%$ & 0.0 & $0.0 \%$ & 0.0 & $0.0 \%$ & 0.0 & $0.0 \%$ & 0.0 & $0.0 \%$ \\
\hline 49 & Financial intermediation & $1,243.68$ & $4.3 \%$ & 1.5 & $0.0 \%$ & 0.0 & $0.0 \%$ & 0.0 & $0.0 \%$ & 1.5 & $0.0 \%$ \\
\hline 50 & Real estate activities & $2,164.56$ & $7.4 \%$ & 0.0 & $0.0 \%$ & 0.0 & $0.0 \%$ & 0.0 & $0.0 \%$ & 0.0 & $0.0 \%$ \\
\hline 51 & Renting of machinery & 941.08 & $3.2 \%$ & 0.0 & $0.0 \%$ & 0.0 & $0.0 \%$ & 0.0 & $0.0 \%$ & 0.0 & $0.0 \%$ \\
\hline 52 & $\begin{array}{l}\text { Public administration and defence; } \\
\text { compulsory social security }\end{array}$ & $1,238.21$ & $4.2 \%$ & 44.7 & $0.7 \%$ & 0.0 & $0.0 \%$ & 0.1 & $0.0 \%$ & 44.8 & $0.1 \%$ \\
\hline 53 & Education & 722.02 & $2.5 \%$ & 5.8 & $0.1 \%$ & 0.0 & $0.0 \%$ & 0.0 & $0.0 \%$ & 5.9 & $0.0 \%$ \\
\hline 54 & Health and social w ork & $1,465.63$ & $5.0 \%$ & 16.9 & $0.3 \%$ & 0.0 & $0.0 \%$ & 0.1 & $0.0 \%$ & 17.0 & $0.0 \%$ \\
\hline 55 & Sew age and refuse disposal & 794.97 & $2.7 \%$ & 40.9 & $0.7 \%$ & 1132.1 & $6.1 \%$ & 0.1 & $0.0 \%$ & 1173.1 & $3.2 \%$ \\
\hline 56 & Private households w ith employed persons & 192.25 & $0.7 \%$ & 0.0 & $0.0 \%$ & 0.0 & $0.0 \%$ & 0.0 & $0.0 \%$ & 0.0 & $0.0 \%$ \\
\hline \multicolumn{2}{|l|}{ Total } & 29,229 & $100.0 \%$ & 6,097 & $100 \%$ & 18,611 & $100 \%$ & 12,065 & $100 \%$ & 36,773 & $100 \%$ \\
\hline \multicolumn{2}{|c|}{$\%$ Total emissions } & & & $16.6 \%$ & & $50.6 \%$ & & $32.8 \%$ & & $100 \%$ & \\
\hline
\end{tabular}

Source: prepared by the authors based on DNTEN (2008), Terra et al. (2009), and

MVOTMA (2010a). 
We constructed a vector of sectoral GHG emissions. The Ministry of Housing, Land Use Planning, and Environment details the 2004 GHG inventory classified by processes (MVOTMA, 2010a). We have constructed GHG emissions accounts following the Eurostat (2009) methodology. We have used secondary sources, like the reports of the National Energy and Nuclear Technology Direction (DNETN, 2008), which detail the structure of net and used energy consumption for the year $2006 .{ }^{3}$

Table 1 depicts the productive sectors' total output (in millions of US dollars) and total GHG emissions (carbon dioxide, $\mathrm{CO}_{2}$, methane, $\mathrm{CH}_{4}$, nitrous oxide, $\mathrm{N}_{2} \mathrm{O}$, and total GHGs, $\mathrm{CO}_{2} \mathrm{e}$, all of them in ktons of $\mathrm{CO}_{2}$-equivalent).

The Uruguayan productive structure in 2005 shows a high weight of service sectors (44 to 55), jointly with Building (43), as well as Cattle farming (6) and Meat production (11). For the analysis below, it is important to note that, on average, $60 \%$ of productive inputs are primary inputs or imports, while $61 \%$ of the production goes to final demand.

Methane emissions represent half of the total emissions of the Uruguayan productive sectors, while nitrous oxide represents one third, and carbon dioxide the remaining $16 \%$. The Cattle farming sector (6) emits almost all the methane and nitrogen oxide, while carbon dioxide emissions mainly come from the Transport sectors (46 and 47).

\section{Empirical results}

The key sector analysis of total GHG emissions for Uruguay is carried out in first place. This is useful for constructing a general view of sectoral responsibilities, as well as for a better understanding of the divergence between unweighted and weighted multipliers. The results of the decomposition of linkages are depicted in second term. This is developed only for the three specific pollutants weighted multipliers analysis, because policy guidelines are only relevant for specific gases considering their weight in total emissions.

Table 2 shows linkages classification computed from equations (1) and (2).When unweighted multipliers are considered eleven key sectors are identified. Only six sectors remain as key when final demand weights are considered: Cattle farming (6), Meat

\footnotetext{
${ }^{3}$ A methodological annex detailing the sectoral allocation of emissions is available upon request.
} 
production (11), Dairy products (15), Tanning and dressing and manufacture of leather (28), Spinning, weaving and finishing of textiles (25), and Rice mill products (16). Moreover, four services sectors, that were not relevant in the unweighted case emerge as key in this case: Hotels and restaurants (45), two Transport-related services (46 and 47) and Sewage and refuse disposal (55). Changes in sector classification when the weight in final demand and primary inputs is considered depict those sectors that are significant as a consequence of their technological structure, but that are not effective for mitigating emissions when their scale is considered. ${ }^{4}$

Table 2: Total GHG $\left(\mathrm{CO}_{2} \mathrm{e}\right)$ backward linkages. Uruguay 2004

\begin{tabular}{|c|c|c|c|c|c|c|c|c|}
\hline & \multicolumn{4}{|c|}{ unweighted } & \multicolumn{4}{|c|}{ weighted } \\
\hline Ranking & Sector № & Sector name & BL & $\mathbf{C V}^{y}$ & Sector № & Sector name & BL & $\mathrm{CV}^{y}$ \\
\hline 1 & 6 & Cattle farming & 27.65 & 7.47 & 11 & Meat production & 1.06 & 7.34 \\
\hline 2 & 11 & Meat production & 16.78 & 7.34 & 6 & Cattle farming & 0.18 & 7.47 \\
\hline 3 & 5 & $\begin{array}{l}\text { Raw milk and milk products } \\
\text { prepared in premises }\end{array}$ & 6.36 & 7.22 & 15 & Dairy products & 0.07 & 6.05 \\
\hline 4 & 1 & Rice growing & 5.20 & 7.31 & 45 & Hotels and restaurants & 0.07 & 6.10 \\
\hline 5 & 25 & $\begin{array}{l}\text { Spinning, weaving and } \\
\text { finishing of textiles }\end{array}$ & 4.72 & 6.63 & 28 & $\begin{array}{l}\text { Tanning and dressing and } \\
\text { manufacture of leather }\end{array}$ & 0.06 & 6.95 \\
\hline 6 & 28 & $\begin{array}{l}\text { Tanning and dressing and } \\
\text { manufacture of leather }\end{array}$ & 4.17 & 6.95 & 55 & Sewage and refuse disposal & 0.05 & 6.91 \\
\hline 7 & 16 & Rice mill products & 3.41 & 6.34 & 47 & Water and air transport & 0.05 & 7.15 \\
\hline 8 & 15 & Dairy products & 3.05 & 6.05 & 25 & $\begin{array}{l}\text { Spinning, weaving and } \\
\text { finishing of textiles }\end{array}$ & 0.05 & 6.63 \\
\hline 9 & 9 & Fishing & 2.85 & 6.83 & 46 & $\begin{array}{l}\text { Land transport; transport via } \\
\text { pipelines }\end{array}$ & 0.05 & 6.83 \\
\hline 10 & 38 & $\begin{array}{l}\text { Other non-metallic mineral } \\
\text { products }\end{array}$ & 2.70 & 6.75 & 16 & Rice mill products & 0.04 & 6.34 \\
\hline 11 & 14 & $\begin{array}{l}\text { Manufacture of vegetable and } \\
\text { animal oils and fats }\end{array}$ & 2.40 & 6.58 & & & & \\
\hline Average & & & 1.90 & 4.74 & & & 0.03 & 4.74 \\
\hline
\end{tabular}

When considering only methane emissions the results are similar, but sectors that were significant due to their emissions from energy combustion are not important in this case (Table A.1 in the Appendix). Methane key sectors include the main direct polluters, Cattle farming (6) and Sewage and refuse disposal (55), which have weighted backward linkages entirely driven through their own components (Figure 1). However, it also includes pure indirect polluters. Pure indirect emissions represent $82 \%$ of total methane emissions (Table 3). They are mainly consequence of agro-industrial sectors that

\footnotetext{
${ }^{4}$ When taking the median as a classification reference, the results change slightly, but are not much relevant to our analysis. The median implies, by definition, that half of the sectors are considered as key, from a demand perspective, a supply perspective, or both. Changing classification criteria to the median multiplier has two main effects on the results: it highlights the whole significance of sectors that were already important from only one perspective, and it atomizes the number of sectors to be considered when some may be not significant. This analysis could be useful when intervention in the most important sectors is not feasible.
} 
demand inputs to direct polluters. A significant part of them is generated due to the demand of other sectors that take a large share of their inputs from them. ${ }^{5}$ This is the case for Tanning and dressing and manufacture of leather (28) and Hotels and restaurants (45). ${ }^{6}$ Almost all of the sectors with a significant pure indirect weighted backward component do not show an important own weighted component. Moreover, their $C V$ value is high. This means that when the demand of these sectors increases they pull only one or a few sectors to pollute (except Rice mill products (16), with a $C V$ of its backward linkages of a little over the mean, but still high, $C V_{16}^{y}=5$ ).

Figure 1: $\mathrm{CH}_{4}$ Backward linkages own and pure indirect components

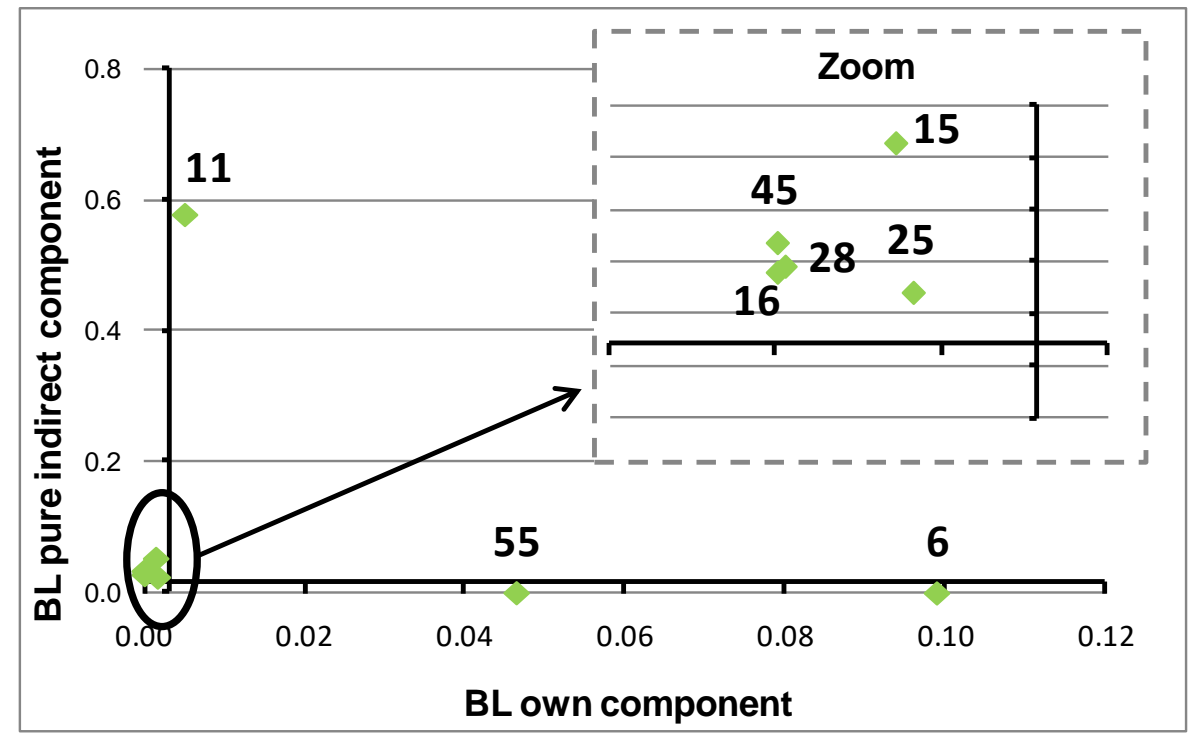

Results for nitrous oxide emissions have many similarities with the ones for methane emissions. This is because the distribution of nitrous oxide direct emissions is almost equal, except for Sewage and refuse disposal (55), which is not significant in this case (Table A.3 in the Appendix).

Direct carbon dioxide emissions are more scattered among sectors than in the previous cases because they mainly come from fossil fuel combustion. Weighted linkages analysis allows to identify five key sectors: Land transport and transport via pipelines (46), Water and air transport (47), Electricity, gas and water supply (42), Refined

\footnotetext{
${ }^{5}$ Using a power series approximation of the Leontief inverse matrix, we computed that around $15.5 \%$ of total methane pure indirect emissions are of a higher order than one.

${ }^{6}$ Sector 45 includes commercial retail trade.
} 
petroleum (33), and Wholesale and retail trade; repair of motor vehicles and motorcycles (44) (Table A.2 in the Appendix).

Sectors 46, 47 and 42 are the main direct carbon dioxide polluters (57.9\%). Their weighted backward linkages are driven mainly by their own components (Figure 2). Looking at the IO matrix, it can be seen that this is because only a small part of their inputs comes from other sectors, while their production is destined mainly to final demand or sold to themselves.

\section{Figure 2: $\mathrm{C}_{2} \mathrm{O}-$ Backward linkages own and pure indirect components}

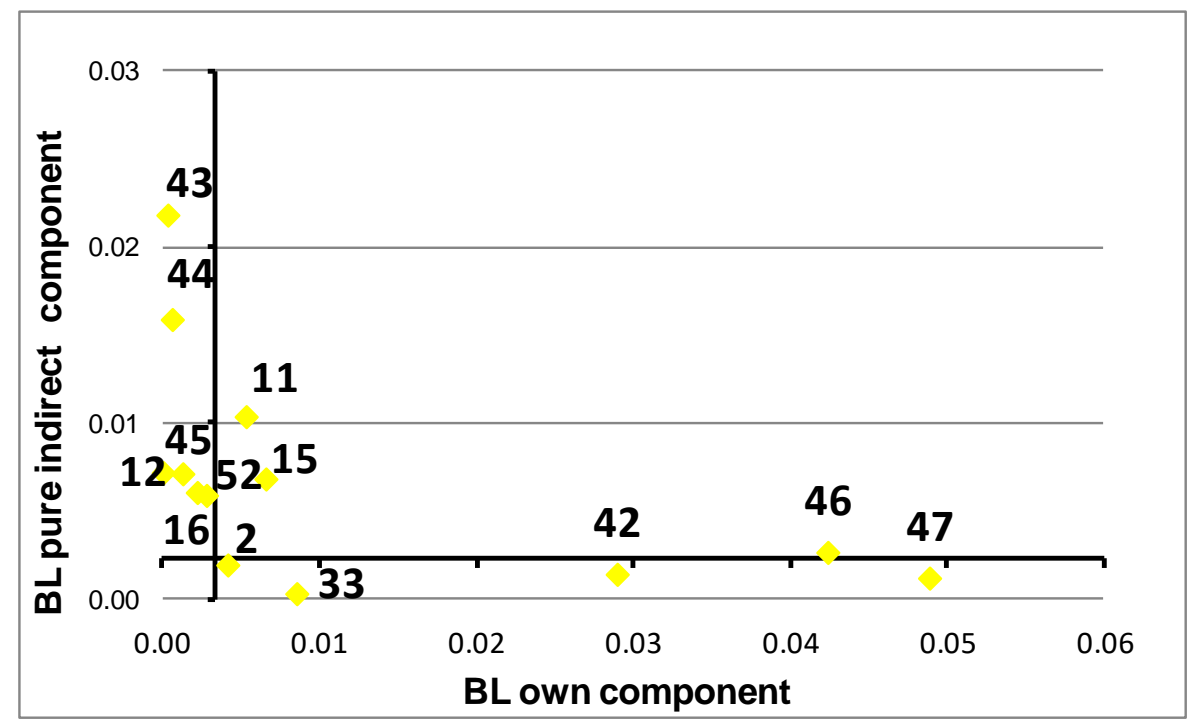

Sector 33 directly emits $6.8 \%$ of total carbon dioxide emissions. Its weighted backward linkages are mainly explained by its own component. This is because of two facts. First, $61.5 \%$ of its production is used as input by other sectors, mainly by other direct $\mathrm{CO}_{2}$ polluting sectors, like Rice growing (1), Raw milk and milk products prepared on the premises (5), Fishing (9), Transport-related sectors (46 and 47), and by sector 33 itself. Second, 93\% of its inputs are primary inputs or imports. Therefore, sector 33 does not pull other sectors so much when its demand increases.

Pure indirect weighted backward linkages are significant in this case (42\% of total carbon dioxide emissions are of this kind, Table 3$).^{7}$ This component explains the importance of the Wholesale and retail trade; repair of motor vehicles and motorcycles (44) sector. Its $C V$ is lower than the average, meaning that increasing this sector's final

\footnotetext{
${ }^{7}$ Around $34 \%$ of total carbon dioxide pure indirect emissions are of a higher order than one.
} 
demand leads many other sectors to pollute. This is because it does not pollute itself but demands inputs from polluting sectors, like Refined petroleum (33), Electricity, gas and water supply (42), Land transport and transport via pipelines (46), and Water and air transport (47).

There are some other sectors that are important because of their pure indirect pollution. In particular, Building (43) pulls Other non-metallic mineral products (38) to pollute, by the time that this later demands inputs from direct polluter sectors. This makes sector 43's pure indirect emissions highly indirect. Similar is the case of Hotels and restaurants (45), which not only demand inputs from direct polluter sectors, but also from sectors that make others pollute.

Finally, while almost all GHG emissions from primary sectors are own (96.8\%), and they are produced to satisfy internal demand (76.6\%), they only represent $11.3 \%$ of total emissions. The case of the industrial sectors is different, as they have the greatest responsibility in total emissions $(74 \%)$, generated mainly indirectly when producing the agro-industrial sectors' exports (Table 3).This pattern is explained by the high weight of methane and nitrous oxide in total emissions. Unlike the above, $\mathrm{CO}_{2}$ emissions are produced mainly to satisfy domestic final demand. This is not surprising because, while methane emissions are embodied in products that rapidly leave the productive system and are generally exported, carbon dioxide emissions are mainly related to fuel combustion and embodied in products that are mainly employed as inputs by other sectors, or destined to domestic consumption. 
Table 3: Own, pure indirect and total GHGs, $\mathrm{CH}_{4}, \mathrm{CO}_{2}$, and $\mathrm{N}_{2} \mathrm{O}$ emissions $\left(\mathrm{CO}_{2}\right.$ equivalent) in Uruguay (2004)

\begin{tabular}{|c|c|c|c|c|c|c|c|c|c|c|}
\hline \multicolumn{11}{|c|}{ Total GHGs emissions ( $\mathrm{CO}_{2}$ eq.) } \\
\hline & \multicolumn{2}{|r|}{ Own } & \multicolumn{2}{|c|}{ Pure } & \multicolumn{6}{|c|}{ Total } \\
\hline Sector & $\begin{array}{c}\text { Own } \\
\text { Ktons }\end{array}$ & $\begin{array}{l}\% \text { Total GHGs } \\
\text { by sector }\end{array}$ & $\begin{array}{l}\text { Pure } \\
\text { Ktons }\end{array}$ & $\begin{array}{l}\% \text { Total GHGs } \\
\text { by sector }\end{array}$ & $\begin{array}{l}\text { Total } \\
\text { Ktons }\end{array}$ & $\begin{array}{l}\text { \%Total } \\
\text { GHGs }\end{array}$ & $\begin{array}{c}\text { Exports } \\
\text { Ktons }\end{array}$ & $\begin{array}{c}\% \text { Total GHGs } \\
\text { by sector }\end{array}$ & $\begin{array}{c}\text { Dom. Cons. } \\
\text { Ktons }\end{array}$ & $\begin{array}{c}\% \text { Total GHGs } \\
\text { by sector }\end{array}$ \\
\hline Primary & 4023.2 & $96.8 \%$ & 133.8 & $3.2 \%$ & 4157.0 & $11.3 \%$ & 972.3 & $23.4 \%$ & 3184.7 & $76.6 \%$ \\
\hline Industrial & 1666.8 & $6.1 \%$ & 25501.5 & $93.9 \%$ & 27168.2 & $73.9 \%$ & 17869.8 & $65.8 \%$ & 9298.4 & $34.2 \%$ \\
\hline Services & 2793.1 & $51.3 \%$ & 2655.1 & $48.7 \%$ & 5448.2 & $14.8 \%$ & 1074.1 & $19.7 \%$ & 4374.1 & $80.3 \%$ \\
\hline Total & 8483.0 & $23 \%$ & 28290.4 & $77 \%$ & 36773.4 & $100 \%$ & 19916.2 & $54 \%$ & 16857.2 & $46 \%$ \\
\hline \multicolumn{11}{|c|}{$\mathrm{CH}_{4}\left(\mathrm{CO}_{2}\right.$ eq. $)$} \\
\hline & \multicolumn{2}{|r|}{ Own } & \multicolumn{2}{|c|}{ Pure } & \multicolumn{6}{|c|}{ Total } \\
\hline Sector & \begin{tabular}{c|} 
Own \\
Ktons
\end{tabular} & $\begin{array}{c}\% \text { Total } \mathrm{CH}_{4} \text { by } \\
\text { sector }\end{array}$ & $\begin{array}{c}\text { Pure } \\
\text { Ktons }\end{array}$ & $\begin{array}{c}\% \text { Total } \mathrm{CH}_{4} \\
\text { by sector }\end{array}$ & $\begin{array}{c}\text { Total } \\
\text { Ktons }\end{array}$ & $\begin{array}{c}\text { \%Total } \\
\mathrm{CH}_{4}\end{array}$ & $\begin{array}{c}\text { Exports } \\
\text { Ktons }\end{array}$ & $\begin{array}{c}\% \text { Total } \mathrm{CH}_{4} \\
\text { by sector }\end{array}$ & \begin{tabular}{|c|}
$\begin{array}{c}\text { Dom. Cons. } \\
\text { Ktons }\end{array}$ \\
\end{tabular} & $\begin{array}{c}\% \text { Total } \mathrm{CH}_{4} \\
\text { by sector }\end{array}$ \\
\hline Primary & 2320.9 & $99.2 \%$ & 19.17 & $0.8 \%$ & 2340.1 & $12.6 \%$ & 490.4 & $21.0 \%$ & 1849.7 & $79.0 \%$ \\
\hline Industrial & 183.8 & $1.3 \%$ & 14140.59 & $98.7 \%$ & 14324.3 & $77.0 \%$ & 9791.9 & $68.4 \%$ & 4532.4 & $31.6 \%$ \\
\hline Services & 894.9 & $46.0 \%$ & 1051.81 & $54.0 \%$ & 1946.7 & $10.5 \%$ & 47.6 & $2.4 \%$ & 1899.1 & $97.6 \%$ \\
\hline Total & 3399.6 & $18 \%$ & 15211.6 & $82 \%$ & 18611.1 & $100 \%$ & 10329.9 & $56 \%$ & 8281.2 & $44 \%$ \\
\hline
\end{tabular}

\begin{tabular}{|c|c|c|c|c|c|c|c|c|c|c|}
\hline \multicolumn{11}{|c|}{$\mathrm{N}_{2} \mathrm{O}\left(\mathrm{CO}_{2}\right.$ eq. $)$} \\
\hline \multirow[b]{2}{*}{ Sector } & \multicolumn{2}{|c|}{$\begin{array}{r}\text { Own } \\
\end{array}$} & \multicolumn{2}{|c|}{ Pure } & \multicolumn{6}{|c|}{ Total } \\
\hline & \begin{tabular}{|c|} 
Own \\
Ktons
\end{tabular} & $\begin{array}{c}\% \text { Total } \mathrm{N}_{2} \mathrm{O} \text { by } \\
\text { sector }\end{array}$ & $\begin{array}{l}\text { Pure } \\
\text { Ktons }\end{array}$ & $\begin{array}{l}\% \text { Total } \mathrm{N}_{2} \mathrm{O} \\
\text { by sector }\end{array}$ & $\begin{array}{l}\text { Total } \\
\text { Ktons }\end{array}$ & $\begin{array}{c}\text { \%Total } \\
\mathrm{N}_{2} \mathrm{O}\end{array}$ & \begin{tabular}{|c|} 
Exports \\
Ktons
\end{tabular} & $\begin{array}{c}\% \text { Total } \mathrm{N}_{2} \mathrm{O} \\
\text { by sector }\end{array}$ & \begin{tabular}{|c|} 
Dom. Cons. \\
Ktons
\end{tabular} & $\begin{array}{l}\% \text { Total } \mathrm{N}_{2} \mathrm{O} \\
\text { by sector }\end{array}$ \\
\hline Primary & 1512.7 & $99.4 \%$ & 9.4 & $0.6 \%$ & 1522.1 & $12.6 \%$ & 381.7 & $25.1 \%$ & 1140.4 & $74.9 \%$ \\
\hline Industrial & 0.9 & $0.0 \%$ & 9902.9 & $100.0 \%$ & 9903.8 & $82.1 \%$ & 6786.1 & $68.5 \%$ & 3117.7 & $31.5 \%$ \\
\hline Services & 12.6 & $2.0 \%$ & 626.5 & $98.0 \%$ & 639.1 & $5.3 \%$ & 21.8 & $3.4 \%$ & 617.3 & $96.6 \%$ \\
\hline Total & 1526.3 & $13 \%$ & 10538.7 & $87 \%$ & 12065.0 & $100 \%$ & 7189.7 & $60 \%$ & 4875.3 & $40 \%$ \\
\hline
\end{tabular}

\begin{tabular}{|c|c|c|c|c|c|c|c|c|c|c|}
\hline \multirow{2}{*}{\multicolumn{3}{|c|}{\begin{tabular}{l|l}
$\mathrm{CO}_{2}\left(\mathrm{CO}_{2}\right.$ eq. $)$ \\
\end{tabular}}} & & & & & & & & \\
\hline & & & \multicolumn{2}{|c|}{ Pure } & \multicolumn{6}{|c|}{ Total } \\
\hline Sector & \begin{tabular}{|c|} 
Own \\
Ktons
\end{tabular} & $\begin{array}{c}\begin{array}{c}\% \text { Total } \mathrm{CO}_{2} \text { by } \\
\text { sector }\end{array} \\
\end{array}$ & $\begin{array}{l}\text { Pure } \\
\text { Ktons }\end{array}$ & $\begin{array}{c}\% \text { Total } \mathrm{CO}_{2} \\
\text { by sector }\end{array}$ & $\begin{array}{l}\text { Total } \\
\text { Ktons }\end{array}$ & $\begin{array}{c}\% \text { Total } \\
\mathrm{CO}_{2}\end{array}$ & \begin{tabular}{|c|} 
Exports \\
Ktons
\end{tabular} & $\begin{array}{c}\% \text { Total } \mathrm{CO}_{2} \\
\text { by sector }\end{array}$ & $\begin{array}{l}\text { Dom. Cons. } \\
\text { Ktons }\end{array}$ & $\begin{array}{l}\% \text { Total } \mathrm{CO}_{2} \\
\text { by sector }\end{array}$ \\
\hline Primary & 189.6 & $64.3 \%$ & 105.3 & $35.7 \%$ & 294.8 & $4.8 \%$ & 100.1 & $34.0 \%$ & 194.7 & $66.0 \%$ \\
\hline Industrial & 1482.1 & $50.4 \%$ & 1458.0 & $49.6 \%$ & 2940.1 & $48.2 \%$ & 1291.7 & $43.9 \%$ & 1648.4 & $56.1 \%$ \\
\hline Services & 1885.5 & $65.9 \%$ & 976.8 & $34.1 \%$ & 2862.4 & $46.9 \%$ & 1004.7 & $35.1 \%$ & 1857.7 & $64.9 \%$ \\
\hline Total & 3557.2 & $58 \%$ & 2540.1 & $42 \%$ & 6097.3 & $100 \%$ & 2396.5 & $39 \%$ & 3700.7 & $61 \%$ \\
\hline
\end{tabular}

Source: prepared by the authors based on DNTEN (2008), Terra et al. (2009), and MVOTMA (2010a). 


\section{Policy implications and conclusions}

Using input-output analysis, we identify key sectors in greenhouse gas (GHG) emissions in the Uruguayan economy. The responsibilities of each sector in terms of its emissions are decomposed into an own component, generated during the activities of the sector and an indirect component, generated by the induced activities in other sectors. This has important implications for the design of mitigation policies. If a sector pollutes through its own production process, technical improvements and best practices are effective in reducing its emissions. Moreover, if a sector is important because it makes other sectors to pollute, technical improvements and better practices are going to be effective only if they reduce intermediate demand to directly polluting sectors. Furthermore, final demand measures can be adopted, although this may not be attractive for policymakers, as it means reducing final demand for several sectors. Total emissions have been split between those produced to satisfy exports and domestic demand. In this sense, our main contributions are twofold: i) we construct a sectoral GHG emissions vector, linking, for the first time in Uruguay, national accounts and the environment; ii) we help to distinguish those sectors where focusing the Climate Change Response Plan (NCCRP) lines of action for mitigation policies (MVOTMA, 2010b) are more effective, as well as those sectors that pull polluters through their pure indirect emissions and are not considered in the NCCRP.

Table 4 shows the classification of the sectors in relationship to their own or pure indirect components. The NCCRP already identifies Cattle farming (6) and Sewage and refuse disposal (55) in their priority lines for methane and nitrous oxide, because of their significance as direct polluters (their joint direct emissions reach $87.5 \%$ of total emissions, Table 1 and Table A.4 in the Appendix). Moreover, 68.9\% of total methane emissions are produced by Meat production (11), Dairy products (15), and Rice mill products (16) when considering direct and indirect emissions. Because these emissions are mainly produced by export-oriented primary sectors, improving productivity in these sectors will mainly increase their final demand rather than diminish emissions.

Moreover, IO multipliers decomposition analysis allows to identify those sectors that pollute through indirect channels, and are not obvious on first inspection. Emissions of a higher order than one account for $12.6 \%$ of total methane emissions. This is the case for Hotels and restaurants (45), a sector that indirectly pulls both the primary and agro- 
industrial sectors to pollute, despite it almost does not produce direct methane emissions (it accounts for $3.5 \%$ of total methane emissions). This indicates that demand policies, like labeling or product process certifications, could be effective. However, given that the cattle farming in Uruguay is produced through extensive technique, the scope of this kind of measure is limited.

Table 4: Weighted linkages $\mathrm{CH}_{4}, \mathrm{~N}_{2} \mathrm{Oand} \mathrm{CO}_{2}$ decomposition and policy measures

\begin{tabular}{|c|c|c|c|c|}
\hline \multirow{2}{*}{$\begin{array}{l}\text { If sector show } \\
\text { important }\end{array}$} & $\mathrm{CH}_{4}$ & $\mathrm{~N}_{2} \mathrm{O}$ & $\mathrm{CO}_{2}$ & \multirow{2}{*}{ Policy implications } \\
\hline & Sector & Sector & Sector & \\
\hline $\begin{array}{l}\text { Own } \\
\text { back ward } \\
\text { component }\end{array}$ & \begin{tabular}{|ll}
6 & Cattle farming \\
1 & Rice growing \\
5 & $\begin{array}{l}\text { Raw milk and milk products } \\
\text { prepared on premises }\end{array}$ \\
55 & Sewage and refuse disposal \\
11 & Meat production
\end{tabular} & 6 Cattle farming & 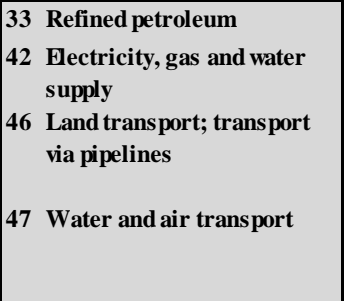 & $\begin{array}{l}\text { Sectoral measures directly } \\
\text { reduce resource use or } \\
\text { environmental degradation: } \\
\text { Technological } \\
\text { improvement and best } \\
\text { practices }\end{array}$ \\
\hline $\begin{array}{l}\text { Pure } \\
\text { back ward }\end{array}$ & $\begin{array}{l}11 \text { Meat production } \\
15 \text { Dairy products } \\
16 \text { Rice mill products } \\
25 \text { Spinning, weaving and } \\
\text { finishing of textiles } \\
28 \text { Tanning and dressing and } \\
\text { manufacture of leather } \\
45 \text { Hotels and restaurants }\end{array}$ & $\begin{array}{ll}11 & \text { Meat production } \\
25 & \text { Spinning, weaving and } \\
\text { finishing of textiles } \\
28 & \text { Tanning and dressing and } \\
\text { manufacture of leather }\end{array}$ & 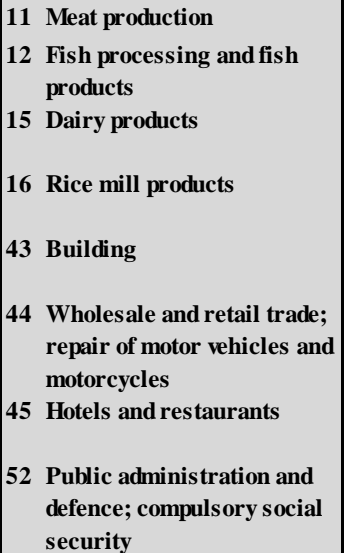 & $\begin{array}{l}\text { Sectoral policies are not } \\
\text { effective, intermediate or } \\
\text { final demand policies are } \\
\text { needed }\end{array}$ \\
\hline
\end{tabular}

As regards carbon dioxide, technical improvements and better practice measures for emissions mitigation should focus on Refined petroleum (33), Electricity, gas and water supply (42), Land transport and transport via pipelines (46), and Water and air transport (47). These are the sectors with greater linkages in terms of GHG emissions (64.7\% of direct emissions and $42.4 \%$ of total, direct plus indirect, emissions). The NCCRP properly distinguishes transport sectors in its priority lines for carbon dioxide mitigation, because of their importance as direct polluters.

However, key sector analysis and weighted multipliers decomposition are particularly relevant in the carbon dioxide case, because emission sources are more disperse. In this case, energy efficiency improvements are also feasible in intermediate demand sectors. Despite this, rebound effects can appear, if the demand from the productive sectors 
increases as a consequence of this efficiency improvement. Multipliers decomposition shows that energy efficiency measures oriented to reduce emissions should focus on Hotels and restaurants (45), and Wholesale and retail trade; repair of motor vehicles and motorcycles (44).These sectors are responsible of $5.2 \%$ and $2.7 \%$ of total carbon dioxide emissions respectively, and almost all are produced through their pure indirect components. Because of this, demand policies on them will reduce emissions in many other sectors. Similar are the cases of Meat production (11), and Dairy products (15), that are responsible for $5 \%$ and $4.2 \%$ of total carbon dioxide emissions respectively, showing high pure indirect weighted backward linkages. However, these sectors are the main exporters, and demand policies are less feasible in this case.

The weighted indirect emissions multipliers of the Building (43) and Real estate activities (50) sectors (7\% and $1.1 \%$ of total carbon dioxide emissions respectively) are also important. The highly indirect emissions of these sectors depict the relevance of housing market and building activities for the design of greenhouse gas mitigation policies. Housing market measures for purchasing and improving second hand houses, instead of building new ones, is an interesting channel for diminishing this pure indirect pollution. Emissions information provided by suppliers on incentives for low-emissions materials substitution is also an effective alternative that can be implemented in the building activities (Acquaye and Duffy, 2010).

Multipliers decomposition suggests that mitigation policies can also be complemented with measures on the Wholesale and retail trade; repair of motor vehicles and motorcycles (44) sector. The oil retail plays an important role in the production of intermediate products. Tax or subsidies can be implemented to encourage cleaner energies in this sector.

Looking further ahead, the technical and cost viability of interventions should be included in the policymaking process. Deciding on which sectors to focus on and the kind of policy mechanisms to apply is a first step towards mitigating the GHG emissions of the Uruguayan production system.

Finally, methane and nitrous oxide emissions are mainly produced by primary sectors when providing inputs to industrial sectors to satisfy their exports. Although $\mathrm{CO}_{2}$ 
emitted to produce exports is significant, these emissions are mainly generated to satisfy domestic demand. Further studies should overcome data availability limitations in order to develop a consumption-based approach for correctly determining Uruguay's responsibility in GHG emissions, and help in the design of complementary GHG mitigation measures.

\section{References}

Acquaye, A.A., and Duffy, A. P. (2010) "Input-output analysis of Irish construction sector greenhouse gas emissions", Building and Environment, Vol. 45, pp. 784-791.

Alcántara, V., del Río, P. and Hernández, F. (2010) "Structural analysis of electricity consumption by productive sectors. The Spanish case", Energy, Vol. 35, pp. 20882098.

Alcántara, V. and Padilla, E. (2006) "An input-output analysis for the "key" sectors in $\mathrm{CO}_{2}$ emissions from a production perspective: an application to the Spanish economy", Working Papers, wpdea0601, Department of Applied Economics at Univesitat Autònoma de Barcelona.

Andrew, R., Peters, G.P., and Lennox, J. (2009) "Approximation and regional aggregation in multi-regional input-output analysis for national carbon footprint accounting”, Economic Systems Research, Vol. 21, No:3, pp.311-335

DNETN (2008) Estudios de base para el diseño de estrategias y políticas energéticas: relevamiento de consumos de energía sectoriales en términos de energía útil a nivel nacional, Asistencia Técnica para la Modernización de los Servicios Públicos en Uruguay, OPP-BM 4598-UR-PNUD-URU/01/010, Ministerio de Industria, Energía y Minería, Dirección Nacional de Energía y Tecnología Nuclear, Uruguay.

Eurostat (2009) Manual for Air Emissions Accounts, Eurostat: Methodologies and Working papers, European Comission.

Hewings, G. (1982) "The empirical identification of key sector in an economy: a regional perspective", The Developing Economies, Vol. 20, № 2, pp. 173-195.

Hirschman, A.O. (1958) The strategy of economic development Yale University Press.

Hoekstra, R. (2005) Economic Growth, material flows and the environment: new applications of structural decomposition analysis and physical Input-Output tables, Advances in Ecological Economics, Edward Elgar Publishing, United Kingdom. 
Hoekstra, R. (2010) “(Towards) a complete database of peer-reviewed articles on environmentally extended input - output analysis" Paper prepared for the $18^{\text {th }}$ International Input - Output conference, June 20-25 ${ }^{\text {th }}$, Sydney, Australia.

Imori, D., and Guilhoto, J.J.M. (2010). "Estrutura produtiva brasileira e emissão de CO2". Em Veiga, J. E. (ed.) (2010) Economia Socioambiental, São Paulo: Editora Senac. ISBN: 9788573599206. pp. 205-233

Jones, L. (1976) "The measurement of Hirschmanian linkages", The Quarterly Journal of Economics, Vol. 90, N², pp. 323-333.

Kondo, Y., Moriguchi, Y. and Shimizu, H. (1998) " $\mathrm{CO}_{2}$ emissions in Japan: influences of imports and exports”, Applied Energy, Vol. 59, №2-3, pp. 163-174.

Lenzen, M. (2003) "Environmentally important paths, linkages and key sectors in the Australian economy", Structural Change and Economic Dynamics, No 14, pp. 1-34.

Lenzen, M., Pade, L.L., and Munksgaard, J. (2004) " $\mathrm{CO}_{2}$ multipliers in multi-region input-output models", Economic Systems Research, Vol ${ }^{\circ} 16, \mathrm{~N}^{\circ}$ 4, pp. 391-412.

Lenzen, M., Murraya,J., Sack, F., and Wiedmann, T. (2007) "Shared producer and consumer responsibility - Theory and practice", Ecological Economics, N ${ }^{\circ}$ 61, pp. 2742.

Leontief, W. (1936) "Quantitive input-output relations in the economic system of the United States", The Review of Economics and Statistics, Vol. 18, № 3, pp. 105-125.

Miller, R. and Blair, P. (2009) Input-Output Analysis: foundations and extensions, Cambridge University Press, $2^{\text {nd }}$ edition.

Munksgaard, J. and Pedersen, K.A. (2001) " $\mathrm{CO}_{2}$ accounts for open economies: producer or consumer responsibility?”,Energy Policy, No 29, pp. 327-334.

MVOTMA (2010a) Third National Communication to the Conference of the Parties in the United Nations Framework Convention on Climate Change, Ministerio de Vivienda, Ordenamiento Territorial y Medio Ambiente, DirecciónNacional de MedioAmbiente, Unidad de Cambio Climático, Uruguay.

MVOTMA (2010b) Plan Nacional de Respuesta al Cambio Climático: diagnóstico y lineamientos estratégicos, Sistema Nacional de Respuesta al Cambio Climático y la Variabilidad, Ministerio de Vivienda, Ordenamiento Territorial y Medio Ambiente.

Peters, G.P. (2008) "From production-based to consumption-based national emission inventories", Ecological Economics, № 65, pp. 13-23. 
Rasmussen, N.P. (1952) Studies in inter-sectorial relation, North-Holland Publishing Company.

Sánchez-Chóliz, J. and Duarte, R. (2003) "Production chains and linkage indicators", Economic System Research, Vol. 15, N², pp. 481-494.

Sonis, M., Hewings, G.J.D., Guo, J. (2000) "A new image of classical key sector analysis: minimum information decomposition of the Leontief inverse", Economic Systems Research, Vol. 12, pp. 401-423.

Terra, M.I. (cord.), Barrenechea, P., Cuadrado, E., Pastori, H., Resnichenko, I. and, Zaclicever, D. (2009) ¿Cuál es la importancia real del sector agropecuario sobre la economía uruguaya?, Oficina de Programación y Política Agropecuaria, Ministerio de Agricultura y Pesca, Acuerdo RED Mercosur-FAO. 


\section{Appendix}

Table A.1: $\mathrm{CH}_{4}$ backward linkages - Uruguay 2004

\begin{tabular}{|c|c|c|c|c|c|c|c|c|}
\hline \multirow[b]{2}{*}{ Ranking } & \multicolumn{4}{|c|}{ unweighted } & \multicolumn{4}{|c|}{ weighted } \\
\hline & Sector № & Sector name & $\mathrm{BL}$ & $\mathrm{CV}^{y}$ & Sector № & Sector name & $\mathrm{BL}$ & $\mathrm{CV}^{y}$ \\
\hline 1 & 6 & Cattle farming & 15.36 & 7.55 & 11 & Meat production & 0.58 & 7.47 \\
\hline 2 & 11 & Meat production & 9.26 & 7.47 & 6 & Cattle farming & 0.10 & 7.55 \\
\hline 3 & 5 & $\begin{array}{l}\text { Raw milk and milk products } \\
\text { prepared in premises }\end{array}$ & 5.90 & 7.51 & 15 & Dairy products & 0.05 & 7.25 \\
\hline 4 & 1 & Rice growing & 4.53 & 4.68 & 55 & Sewage and refuse disposal & 0.05 & 7.49 \\
\hline 5 & 16 & Rice mill products & 2.60 & 5.04 & 45 & Hotels and restaurants & 0.03 & 6.88 \\
\hline 6 & 25 & $\begin{array}{l}\text { Spinning, weaving and } \\
\text { finishing of textiles }\end{array}$ & 2.48 & 7.06 & 28 & $\begin{array}{l}\text { Tanning and dressing and } \\
\text { manufacture of leather }\end{array}$ & 0.03 & 7.42 \\
\hline 7 & 15 & Dairy products & 2.44 & 7.25 & 16 & Rice mill products & 0.03 & 5.04 \\
\hline 8 & 28 & $\begin{array}{l}\text { Tanning and dressing and } \\
\text { manufacture of leather }\end{array}$ & 2.20 & 7.42 & 25 & $\begin{array}{l}\text { Spinning, weaving and } \\
\text { finishing of textiles }\end{array}$ & 0.03 & 7.06 \\
\hline 9 & 55 & Sewage and refuse disposal & 1.51 & 7.49 & & & & \\
\hline 10 & 14 & $\begin{array}{l}\text { Manufacture of vegetable and } \\
\text { animal oils and fats }\end{array}$ & 1.19 & 7.45 & & & & \\
\hline Average & & & 0.95 & 5.64 & & & 0.02 & 5.64 \\
\hline
\end{tabular}

Table A.2: $\mathrm{CO}_{2}$ backward linkages - Uruguay 2004

\begin{tabular}{|c|c|c|c|c|c|c|c|c|}
\hline \multirow[b]{2}{*}{ Ranking } & \multicolumn{4}{|c|}{ unweighted } & \multicolumn{4}{|c|}{ weighted } \\
\hline & Sector № & Sector name & BL & $\mathrm{CV}^{y}$ & Sector № & Sector name & BL & $\mathrm{CV}^{y}$ \\
\hline 1 & 9 & Fishing & 1.1E-04 & 7.15 & 47 & Water and air transport & 2.1E-06 & 7.30 \\
\hline 2 & 38 & $\begin{array}{l}\text { Other non-metallic mineral } \\
\text { products }\end{array}$ & $1.1 \mathrm{E}-04$ & 6.88 & 46 & $\begin{array}{l}\text { Land transport; transport via } \\
\text { pipelines }\end{array}$ & $1.8 \mathrm{E}-06$ & 7.03 \\
\hline 3 & 47 & Water and air transport & 6.7E-05 & 7.30 & 42 & Electricity, gas and water & 1.2E-06 & 7.12 \\
\hline 4 & 46 & Land transport; transport via & $6.1 \mathrm{E}-05$ & 7.03 & 43 & Building & $9.1 \mathrm{E}-07$ & 5.17 \\
\hline 5 & 31 & Paper and paper products & 5.3E-05 & 6.39 & 44 & $\begin{array}{l}\text { Wholesale and retail trade; } \\
\text { repair of motor vehicles and } \\
\text { motorcycles }\end{array}$ & $6.8 \mathrm{E}-07$ & 3.76 \\
\hline 6 & 42 & Electricity, gas and water & 4.9E-05 & 7.12 & 11 & Meat production & 6.4E-07 & 3.05 \\
\hline 7 & 18 & Prepared animal feeds & $4.2 \mathrm{E}-05$ & 5.50 & 15 & Dairy products & 5.5E-07 & 3.97 \\
\hline 8 & 12 & Fish processing and fish & 3.8E-05 & 6.34 & 33 & Refined petroleum & 3.6E-07 & 7.18 \\
\hline 9 & 21 & Wines & 3.4E-05 & 5.12 & 16 & Rice mill products & 3.6E-07 & 3.83 \\
\hline 10 & 16 & Rice mill products & 3.3E-05 & 3.83 & 45 & Hotels and restaurants & 3.5E-07 & 2.14 \\
\hline 11 & 1 & Rice growing & 2.7E-05 & 6.28 & 52 & Public administration and & 3.4E-07 & 3.49 \\
\hline 12 & 15 & Dairy products & 2.5E-05 & 3.97 & 12 & Fish processing and fish & 3.0E-07 & 6.34 \\
\hline 13 & 30 & Wood products & 2.3E-05 & 5.91 & 2 & Other cereals and crops & 2.5E-07 & 5.16 \\
\hline 14 & 7 & Other animal farming & $2.0 \mathrm{E}-05$ & 3.93 & & & & \\
\hline Average & & & $1.9 \mathrm{E}-05$ & 4.28 & & & 2.3E-07 & 4.28 \\
\hline
\end{tabular}

Table A.3: $\mathrm{N}_{2} \mathrm{O}$ backward linkages linkages- Uruguay 2004

\begin{tabular}{|c|c|c|c|c|c|c|c|c|}
\hline \multirow[b]{2}{*}{ Ranking } & \multicolumn{4}{|c|}{ unweighted } & \multicolumn{4}{|c|}{ weighted } \\
\hline & Sector № & Sector name & $\mathrm{BL}$ & $\mathrm{CV}^{y}$ & Sector № & Sector name & $\mathrm{BL}$ & $\mathrm{CV}^{y}$ \\
\hline 1 & 6 & Cattle farming & 5.0E-04 & 7.48 & 11 & Meat production & $1.9 \mathrm{E}-05$ & 7.48 \\
\hline 2 & 11 & Meat production & 3.0E-04 & 7.48 & 6 & Cattle farming & 3.2E-06 & 7.48 \\
\hline 3 & 25 & $\begin{array}{l}\text { Spinning, weaving and } \\
\text { finishing of textiles }\end{array}$ & 7.5E-05 & 7.48 & 45 & Hotels and restaurants & $9.8 \mathrm{E}-07$ & 7.47 \\
\hline 4 & 28 & $\begin{array}{l}\text { Tanning and dressing and } \\
\text { manufacture of leather }\end{array}$ & 7.0E-05 & 7.48 & 28 & $\begin{array}{l}\text { Tanning and dressing and } \\
\text { manufacture of leather }\end{array}$ & 9.4E-07 & 7.48 \\
\hline 5 & 14 & $\begin{array}{l}\text { Manufacture of vegetable and } \\
\text { animal oils and fats }\end{array}$ & 3.8E-05 & 7.47 & 25 & $\begin{array}{l}\text { Spinning, weaving and } \\
\text { finishing of textiles }\end{array}$ & 7.9E-07 & 7.48 \\
\hline 6 & 29 & Footwear & 2.6E-05 & 7.48 & & & & \\
\hline 7 & 45 & Hotels and restaurants & 2.4E-05 & 7.47 & & & & \\
\hline Average & & & 2.0E-05 & 6.61 & & & 4.6E-07 & 6.61 \\
\hline
\end{tabular}


Table A.4: National Climate Change Response Plan lines of action for GHGs emission mitigation

\begin{tabular}{|c|c|c|}
\hline \multirow{10}{*}{ 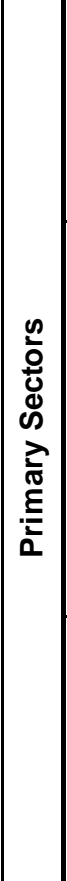 } & \multirow{3}{*}{$\begin{array}{l}\text { Cattle farming } \\
\text { and dairy } \\
\text { products }\end{array}$} & $\begin{array}{l}\text { Best practices in dairy and cattle closures manure management for reducing } \\
\text { methane emissions }\end{array}$ \\
\hline & & Improving animal diets with prairie planting \\
\hline & & Soil carbon sequestration through productivity of pastures promotion \\
\hline & \multirow{4}{*}{ Agriculture } & $\begin{array}{l}\text { Soil carbon sequestration through reduced tillage methods, direct seeding and } \\
\text { proper selection of crop sequences or pastures rotations }\end{array}$ \\
\hline & & $\begin{array}{l}\text { Promoting innovative management of irrigation and fertilization practices for reducing } \\
\text { methane emissions from flooded rice cultivation }\end{array}$ \\
\hline & & Encourage fossil fuels substitution by agricultural and agroindustrial waste biomass \\
\hline & & Increase fossil energy and nitrogen fertilizer use efficiency \\
\hline & \multirow{3}{*}{$\begin{array}{l}\text { Forests and } \\
\text { Forestry }\end{array}$} & Encourage efficient forest plantations as carbon sink development \\
\hline & & $\begin{array}{l}\text { Encourage use of wood residues from forests and forest industry as alternative } \\
\text { energy sources }\end{array}$ \\
\hline & & $\begin{array}{l}\text { Promote native forests protection and enhance their protection through a more } \\
\text { efficient application of existing legislation }\end{array}$ \\
\hline \multirow{5}{*}{ के } & $\begin{array}{l}\text { Energy matrix } \\
\text { diversification }\end{array}$ & $\begin{array}{l}\text { Support specific initiatives of the Strategic Energy Development guidelines for } 2015 \\
\text { goals }\end{array}$ \\
\hline & $\begin{array}{l}\text { Energy } \\
\text { efficiency }\end{array}$ & $\begin{array}{l}\text { Ensure continuity of energy efficiency policies developed in the Energy Efficiency } \\
\text { Project of the DNE-Uruguay }\end{array}$ \\
\hline & \multirow{3}{*}{$\begin{array}{l}\text { Emissions } \\
\text { reduction }\end{array}$} & $\begin{array}{l}\text { Identify GHGs mitigation measures for the energy sector, and consider it application } \\
\text { in different industries. }\end{array}$ \\
\hline & & $\begin{array}{l}\text { Define and apply energy efficiency standards and norms, in reference to building } \\
\text { materials thermal properties and building characteristics }\end{array}$ \\
\hline & & Residential and services lighting systems efficiency improvement \\
\hline \multirow{4}{*}{ 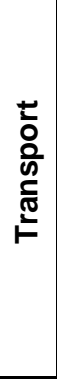 } & \multirow{4}{*}{$\begin{array}{l}\text { Energy } \\
\text { consumption } \\
\text { reduction }\end{array}$} & $\begin{array}{l}\text { Define plans and policies that would help reduce energy consumption, diversifying } \\
\text { the energy matrix and defining actions to improve transport energy use efficiency }\end{array}$ \\
\hline & & $\begin{array}{l}\text { Improve public transport systems for passengers and cargo transport efficiency } \\
\text { through alternative transportation and energy sources }\end{array}$ \\
\hline & & $\begin{array}{l}\text { Promote more energy efficient transportation and to continue replacing fossil fuels } \\
\text { with biofuels }\end{array}$ \\
\hline & & Evaluate the potential of the Uruguay river navigation development \\
\hline \multirow{2}{*}{$\frac{0}{5}$} & \multirow{2}{*}{$\begin{array}{l}\text { Emissions } \\
\text { reduction }\end{array}$} & $\begin{array}{l}\text { New urban biogas capture landfill for reducing methane emissions from } \\
\text { decomposition of solid waste }\end{array}$ \\
\hline & & $\begin{array}{l}\text { Promote industrial processes wastewater treatment plants anaerobic lagoons } \\
\text { replacement by anaerobic intensive processes }\end{array}$ \\
\hline 吾 & & $\begin{array}{l}\text { Public strategy design for taking advantage of opportunities for supporting } \\
\text { sustainable developing that can exist }\end{array}$ \\
\hline
\end{tabular}

